\title{
Fast Food Nationalism: Culinary Politics and Post-colonial Imaginaries in Trinidad and Tobago
}

\author{
Aaron Andrew Greer \\ Department of Sociology \& Anthropology, Pacific University, USA
}

Copyright $(2016$ by authors, all rights reserved. Authors agree that this article remains permanently open access under the terms of the Creative Commons Attribution License 4.0 International License

\begin{abstract}
Projects of nationalism in the post-colonial Caribbean have proven difficult to implement and sustain. Beleaguered by low revenues and high crime, extreme class inequality and high emigration rates, economic policies imposed by imperial powers and anemic investment in domestic programs and infrastructure, and governments destabilized by a congeries of external and internal forces, Caribbean countries have faced the daunting task of forging durable nationalist projects that promote investment of all kinds both by the state and the nation. Using an anthropology of the contemporary, I identify and analyze how the problem of post-colonial nationalism is evident in and affected by the presence of a fast food chain in Trinidad and Tobago.
\end{abstract}

Keywords Trinidad, Fast Food, Nationalism, Fragmentation, Assemblage, Post-colonial

\section{Introduction: The Colonel in the Caribbean}

If food is treated as a code, the messages it encodes will be found in the pattern of social relations being expressed. The message is about different degrees of hierarchy, inclusion and exclusion, boundaries and transactions across the boundaries.

\section{$\sim$ Mary Douglas, Deciphering a Meal}

The KFC at Independence Square in Trinidad's capital city, Port of Spain, is among the chain's highest revenue earners in the world ${ }^{1}$. Its doors are passed by thousands of consumers every day. The crisp red and white backdrop behind the iconic picture of the genteel Southern chef in a bow-tie stands in stark contrast to the drab, color-faded old colonial buildings falling into disrepair around it. The Colonel looms high above Captain Cipriani, an early $20^{\text {th }}$

\footnotetext{
${ }^{1}$ Neither KFC nor its parent company, Yum! Brands, release data on specific franchise revenue, so ascertaining the Port of Spain store's exact place among contenders for busiest worldwide is difficult. However, the Port of Spain KFC regularly boasts in its promotional ads that it is among the world's busiest, which, purely by anecdotal data is not surprising.
}

century nationalist and agitator for colonial rights, who stands as the centerpiece of Independence Square. While the trinity of fried chicken chains at Independence Square - a KFC, a Church's, and the local Royal Castle - stands as testament to Trinidadians' voracious appetite for fried foods, it also silently weaves a tale of imperial dominance and Trinidad's quest for a viable nationalism in the face of numerous forms of Western cultural hegemony. I argue here that the problems of postcolonial nationalism attendant in the years preceding and during Trinidad and Tobago's Independence continue to beleaguer the nation. Those problems emerge, as they do in many postcolonial countries, from an underdeveloped economy forced into business with much larger political-economies and are evident in countless spheres of national life, in this case, the presence and dominance of a fast food chain. I argue that food consumption patterns can be, and in many cases are, a reflection of a country's nationalist history.

This paper will explore problems of Trinidadian postcolonial nationalism and the way in which fast food is a symbol and symptom of its struggles with national identity in the face of Western cultural imperialism. Following Rainbow, this exploration allows us to decompose assemblages composed of colonialism, capitalism, and nationalism and examine their influence on food consumption patterns [1]. Attendant in this assemblage then are issues of public health and well-being, food security for a small island nation, the source and quality of food, and the changing tastes of consumers as more of the world's people consume fast food. Each of these cannot be treated in the detail they deserve here. However, the argument I wish to make throughout this paper is that this litany of problems wrought by the globalization of fast food consumption patterns is a symptom of larger, geo-economic processes and emblematic of the "fragmented nationalisms" of the West Indies [2, 3].Generating a viable nationalist project, I will argue, is contingent in large measure upon the agency to shape and direct global political-economic forces within the state. As nationalist theorist Harry Johnson states, "As an ideology or state of political feeling, nationalism can be conceived of...as attaching utility or value to having certain 
jobs held or certain property owned by members of the national group rather than by non-members of the national group" [4]. Johnson articulates here a link between economic agency and nationalism (economic nationalism) that neatly captures a nagging problem in the post-colonial world: how to fashion an economically solvent state that adequately serves its nation in a global order dominated by empire. Trinidad then is emblematic of many other small, post-colonial states struggling to forge a strong national identity as a relatively insignificant geo-economic actor in the face of massive foreign ownership groups. Food, in this case fast food, is thus linked in imaginative geographies of the national self with the agency to create and sustain local food production. In distinction to Wilk's [5] description of the creation of a national cuisine in Belize, under analysis here is the intrusion of an international cuisine in an already bountiful market of national foods.

Some questions under consideration are: How does a multi-national fast food chain gain purchase in a country that already has its own industry of the same cuisine? Why is the local option less desirable than the American one? How is food, fast food specifically, linked with nationalist economies and geographies? Following Mary Douglas, what messages are encoded and what hierarchies are expressed in the global dominance of certain foods and certain food chains? The social lives of foods are every bit as complex, messy [6] and at times aggravatingly inscrutable as humans', so answering these questions, and the many others than spring from them, may at times be circuitous, unconventional, and perhaps even messy. What follows is my clearest attempt to untangle the troublesome knot of legacies and their lingering affects on contemporaries [1].

The data collected for this research derived from several ethnographic methods, which included interviews, observations, discussions, and archival research. I employed these methods in order to tease out the ways in which food can operate as a signifier of national sentiment and the complicated means by which nationalist foundation narratives can include the seemingly mundane practice of food consumption. In a country with such a rich creole culinary tradition, how does the popularity of an American chain restaurant fit into narratives of food? Answering this question thus required ethnographic methods, particularly interviews, in conjunction with archival resources.

\section{From 'Workshop' to State: A Very Brief History of Nationalism in Trinidad and Tobago}

Four centuries of colonialism, from 1498 to 1897, had made of Trinidad and Tobago a great workshop rather than a miniature state.

$\sim$ Eric Williams, History of the People of Trinidad and Tobago

Nationalism in Trinidad has progressed in fits and starts. It wasn't until the 1920s, after Trinidadian members of the British West Indies Regiment fought alongside allied powers in WWI, that a true struggle for self-determination began. Frustrated with their treatment during the war as second-class soldiers and the lack of recognition they received for their efforts at the war's end, agitators such as Captain Arthur Cipriani mobilized a band of veterans and disaffected workers chafing under the yolk of imperial labor policy to denounce British colonial rule and advocate for increased administrative power for Trinidadians $[7,8]$. This small movement gave way to the well-known labor riots of 1937 when Indo - and Afro-Trinidadian oil, sugar, and cocoa workers stood in solidarity against retrograde labor policies that continued the exploitation as usual practices of pre-emancipation and indentured servitude [9]. Despite the agitations and protestations of the 1920s and 30s led by Captain Arthur Cipriani, followed by labor agitators and nationalists like Adrien Cola Rienzi and Tubal Uriah Butler, it was not until the 1950s, under the leadership of nationalists such as Eric Williams and Albert Gomes, that Trinidadians would begin a sustained independence movement [10]. Victory for the nationalists finally arrived in 1962 when formal governance was transferred from British to Trinidadian hands ${ }^{2}$.

By Caribbean standards Trinidad is a mid-size island, populated by just over a million people. Like many former colonies throughout the Caribbean, and the world for that matter, Trinidad struggles to make its way in a global order dominated by larger, more politically, economically, and culturally powerful nations. Trinidad is unique as a West Indian state for its short history as a labor colony, its ethnically diverse population, its robust economy due to abundant supplies of oil and natural gas, and its largely peaceful history. Yet Trinidad shares with its Caribbean neighbors a history of oppression under European control that continues to shape its present and future, confounding nationalist projects that appear effortless in imperial countries. As European influence began to wane in the late $19^{\text {th }}$ century, the US has assumed greater influence in the region, first through military interventions and later through various forms of economic and cultural imperialism [11]. The greater political-economic influence from the Unites States, coupled with increasing migration to the north (including Canada), has meant a gradual turning away from England as cultural metropole in favor of American trends and styles. As V.S. Naipaul has pointed out, America is practically synonymous with modernity in Trinidad. Though Trinidad produces some of the finest coffee in the world, he laments, locals can be found sipping Nescafe, the more modern beverage "advertised in American magazines " [12].

\footnotetext{
${ }^{2}$ The handover from imperial rule to self-governance can be viewed on YouTube under the title This Land of Ours Part 4 (https://www.youtube.com/watch?v=EgQzobAtQ-4). The figure in his signature dark sunglasses accepting the Constitution is Eric Williams.

3 Trinidad now has its own chain of coffee shops called Rituals (motto: Grounds for Enjoyment). Bordering on copyright infringement with Starbucks, the café does serve locally and regionally sourced coffee, though not exclusively. Astoundingly, Nescafe remains extremely popular in Trinidad, found in almost every home I've visited over the last seven years.
} 
That Trinidad has struggled so mightily to forge a viable nationalist project is, paradoxically, both obvious and an enigma. Trinidad's nationalist paradox deserves richer detail than can be engaged here, though it is worth outlining, even if only impressionistically, these polarities. The nationalist enigma rests in the simple fact that between the two islands that make up the state, Trinidad and Tobago has resources of many kinds, and in surplus. Oil and natural gas found the bulk of the state's annual revenue, which makes the twin island nation unique among Caribbean nations. Add to those commodities Tobago's largely undeveloped rain forest interior framed by vibrant coral reefs and white sand beaches, and it becomes clear that Trinidad and Tobago has the requisite economic agency to fashion itself as a regional micro-power. Additionally, save for a rather bizarre coup that lasted every bit of a week in 1990, Trinidad has had a remarkably peaceful, largely uneventful, political history since Independence in 1962. Given Trinidad and Tobago's enviable resources and comparative peacefulness, the country's difficulties with national investment remain rather enigmatic.

Troublingly, Trinidad's relative political-economic strength has not translated into national investment. Thus, viewed in broader historical and contemporary geo-political/cultural context, Trinidad's difficulties are not so enigmatic. Though markers of national pride are evident on the surface of Trinidadian life, they belie a widespread disillusionment with the state and an abiding tradition of cynicism among the nation. Despite Trinidad's predictably strong GDP figures, the net migration rate is, year after year, in the negative, currently holding at -6 percent. A convoluted imperial past, involving several exchanges of Trinidad and Tobago between colonial powers, an exceedingly plural society on nearly every count - ethnic, religious, cultural and foreign ownership of key resources coupled with western imposed economic policies combine in ways that have increased the nation's dependency on foreign ownership and hegemonic states. Gaining independence then is not accomplishment enough from which to write a compelling "foundation myth", as Knight phrases it [2]. Looked at another way, if independence does not translate into local ownership and political-economic power, that independence is certainly necessary for a viable nationalist project, but not sufficient. Beyond mere political sovereignty then, a post-colonial nation-state requires as at least one factor among a great many, a certain measure of autonomy and agency to produce not just consumer goods, but also the intangibles of local imaginaries.

Food is a clear example of the creative work of local imaginaries. In this regard, Trinidad is in no short supply of creativity. The twin island country sets the standard for definitions of "creole" in nearly every quarter. Whole continents of cultural history and practice collide in Trinidad. Africa, Asia, Europe, the Middle East, South America, and more recently North America, all have a clearly identifiable, documentable, and analyzable presence there. Along with the vestiges of indigenous Caribs [13], the foods of Trinidad reflect the broader cultural creolism of the nation. Roti (flat bread wrapped around stewed curry, burrito style), buss-up shut (pile of flat bread beside stewed curry), doubles (curried chana in fried flat bread, eaten taco style), provisions (stewed or steamed local root vegetables), macaroni pie (macaroni and cheese casserole), and bake and shark (shark sandwich in fried bread) are some of the most iconic dishes in Trinidad and Tobago, each reflecting both its origins and its creole locality. Food, one could reasonably argue then, constitutes a large part of a nation-state's foundation myth, narrating to the self and others its complex histories and mutable contemporary influences and imaginaries. How then does a massive, multi-national corporate fast food chain originating in an imperial country become part of a contemporary foundation myth? If we are to understand a foundation myth as the narrative a nation-state rehearses about itself, and which includes its local cuisines, how does a global restaurant chain implicate itself in that narrative?

\section{3. 'We Food': Indigenizing KFC}

While KFC may not necessarily be viewed as more modern than its local counterpart, Royal Castle, by its association with the US, it is certainly viewed as superior to the local options, evidenced if nothing else by its distinction as one of the world's busiest KFC branches. And KFC in Trinidad delivers. Their red and white scooters, decked out with insulated boxes on the back, can be seen at all hours of the day and night, zipping through Port of Spain's narrow and crowded streets, delivering buckets of fried chicken to famished Trinis ${ }^{4}$. KFC's fried chicken dominion in Trinidad is helped along as well by the ubiquitous billboard, radio, and TV ads that use generous helpings of Trinidadian dialect to create a sense of ownership with the international franchise. TV ads feature local Rapso, Calypso, and Soca artists such as Iwer George and Ziggy Rankin declaring, "Good for me every lime, lime/ good for me every time, time. ${ }^{5 \text { " On a }}$ Yahoo hosted chat site, locals, appearing to be simply chatting about KFC's excellence, state in dialect things like, "The sad thing about this is the KFC in the States doh taste like KFC in Trini. And get this, dey doh [they don't] deliver. You could bet that? Sweet TnT". GibbsyGirl replies,

Yeah boy TS, that not delivering thing is a real down fall here in the States. I will never forget Ash Wednesday 2004, me, meh sister and meh cousin hungry fuh so but everybody tail so sore from Carnival that nobody could get up to fix nothing to eat so we order KFC. We order we food, matter fix and we feeling good because no had to get up. The joke though was when de mister reach by the gate and ringing the bell hell hard and all three ah we now

\footnotetext{
4 'Trini' is the local term for Trinidadian, which I use here to evoke contexts of usage.

${ }_{5}$ To lime (v.) is to gather in a group informally to chat, hang out, drink, or eat (each of these activities being sufficient to constitute a lime, not necessary). A lime (n.) is thus an "informal gathering"
} 
looking at each other to see who getting up to get the food!!

The not so spontaneous chat goes on like this, rhapsodizing in local dialect about KFC's 24 herbs and spices or the juiciness of the chicken. The effect of the chat, as with the Soca TV spot, is one of indigenization - KFC becomes associated with Trinidad as a point of local pride. Later in the chat, ilyena proudly offers,

A lil statistic for you...

KFC on Independence Square (the branch NEVER closes) has the highest sales record for a single branch in KFC's worldwide.

No other KFC outsells them...

We love we chicken... they raise de price... we just look for de extra dollar...

On the corner across from KFC at the St. James taxi stand is the blue and gold awning of Church's Fried Chicken, more modest than the KFC, but sitting on respectable real estate nonetheless. And right next door, adorned in red and yellow, sits the forlorn Royal Castle Chicken, emblazoned with its nationalistic motto in Standard English, Our Taste, Our Culture, frequented perhaps by those unwilling to withstand the long lines that often snake out the door at KFC. Or perhaps by those thirsty for the local mauby drink unobtainable at the American restaurant ${ }^{6}$. Royal Castle is smaller, far less busy, less noisy, and a bit less clean. The lines are also less imposing, which, typically, does not necessarily mean shorter wait times for orders. Royal Castle's business model, menu, and scaled down aesthetics border on copyright infringement with $\mathrm{KFC}$, an instance of what Richard Wilk might call a 'structure of common difference' [14]. What one gets at Royal Castle is not terribly different than what one gets at KFC, but, of course, one comes with association with power, prestige, and sophistication, the other simply a home-grown operation [15]. It is within this seemingly insignificant difference, long lines at KFC, short ones at Royal Castle, from which we can metonymically read the problem of nationalism in Trinidad. With the exception of very few local products (both material and conceptual) Trinidadians tend to be crushingly disparaging of their own creations. They speak of each other, both inter- and intra-racially, in the most damningly cynical terms and assume that whatever is made in Trinidad is done so either for the easy money or extremely shoddily. Or both, but rarely neither. This may go some distance toward accounting for the traction of foreign policies that typically benefit the powerful. In short, it is a foundation myth in need of retrofitting.

\section{Kentucky Fried Neo-liberalism}

You [the imperialist] will forget your part in the whole setup, that bureaucracy is one of your inventions, that Gross

\footnotetext{
${ }^{6}$ As one Trinidadian reported, mauby is "a kinda local root beer." Made from the root of a mauby tree, the drink has an intensely sweet beginning, followed immediately by an equally intense bitterness that few visitors find appealing. Trinidadians often tout its medicinal qualities as a hydration aid.
}

National Product is one of your inventions, and all the laws that you know mysteriously favour you.

$\sim$ Jamaica Kincaid, A Small Place

The trinity of fried chicken shacks at Independence square - KFC, Church's, Royal Castle - weaves an ironic tale about independence in an era of import food dependency, signaling not simply the globalization of tastes, aesthetics, style, but also of trade policies and the ideologies that underwrite them. Not only has Trinidad, as with many other Caribbean island states, fallen under the spell of American popular culture and its countless brands, it has also become enmeshed in a largely US driven neo-liberal economic model that favors private enterprise over state programs, offers fewer subsidies for local entrepreneurs, promotes the eradication of any form of trade barriers or protectionism, and requires full inclusion in global networks of free trade. The growing body of literature on the failure of these policies, particularly economist Ha-Joon Chang's two books Kicking Away the Ladder [16] and Bad Samaritans [17], is testament to the failure of western economic models for the developing world. Throughout the long Reagan-Thatcher years, and into the present, the developing world has been forced to contend with the already robust and powerful economies of the West. Under free-trade and loan agreements signed and doled out since the late 1980s, Caribbean nations and their fledgling industries have been asked to compete against well-established multi-national corporations with financial resources exceeding the GNP of many nations and with the full backing of the powerful US government (on the US backed 'postmodern' economy, see Jameson $[18]^{7}$ ). A well-covered example of the devastation of these policies is Jamaica, vividly chronicled in Stephanie Black's documentary Life and Debt [19].

Jamaica's small, yet largely self-sustaining local economy now lies in tatters, torn apart by neo-liberal structural adjustment policies (SAPs) that one by one dismantled their fruit industry, their dairy industry, their meat producing industry, and even their local restaurant industry. After US companies devoured Jamaica's local industries and bought up the island's choicest real estate on which to build its lush resorts, Jamaicans have been left few options for work outside of its ever expanding shadow economies involving prostitution, arms trading, and drug trafficking ${ }^{8}$.

Jamaica, of course, is not alone. The litany of troubles Jamaica faces as it attempts to negotiate late capitalism is the same litany faced by many of its sister nations throughout the Caribbean, in all their myriad iterations. Trinidad has

\footnotetext{
${ }^{7}$ In his inimitably overstated style, Jameson lays the blame for global economic disparity at American feet. "Yet this is the point at which I must remind the reader of the obvious; namely, that his whole global, yet American, postmodern culture is the internal and superstructural expression of a whole new wave of American military and economic domination throughout the world: in this sense, as throughout class history, the underside of culture is blood, torture, death, and terror" [18].

${ }_{8}$ There is also the unsavory option of cutting sugar cane in Florida under the $\mathrm{H}-2$ program, a guest worker scheme that allows foreign laborers, in the case of cane cutting mostly Jamaicans, to enter the US to work in the agriculture industry. To no one's surprise, the program is exploitative in the extreme with low pay, expensive company stores, virtually no health care, and little worker agency to make changes. The system recalls England's experiments

with indenture programs after Emancipation in 1833.
} 
certainly not suffered the destruction of its local industries quite as severely as Jamaica, but neither has it entirely escaped a similar fate. Despite Trinidad's vast rural areas in the interior (most of which is arable land), current figures reveal that less than four percent of Trinidad's labor force is engaged in agriculture ${ }^{9}$. By comparison, sixty three percent of the workforce is service based, mostly in low-end, non-union jobs like retail sales or restaurant work. Interestingly, on my first visit to Trinidad in 2006, then Prime Minister Patrick Manning declared the official end of Trinidad's fabled sugar industry. Competition from outside and the higher prices demanded by Trinidad's sugar workers union spelled the end of its nearly two-hundred year presence.

Winston Dookeran, running against Prime Minister Patrick Manning in that year's national election, made revival of the sugar industry part of his central platform, though nobody appeared to take him seriously and the subject has not been brought up since. When I had the chance to meet briefly with Dookeran after a kind of town hall style meeting, I asked him about his plan to revive the sugar industry. He admitted to concerns that sugar would never regain its primacy as an economic driver of Trinidadian GDP. That vast fields of cane were going completely unused, however, seemed to him a tragic waste. Though most Trinidadians readily dismissed the notion of reviving the moribund sugar industry, I empathized with Dookeran. Whole seas of sugar cane grow wildly now throughout Central and South Trinidad, bearing the signs of years of neglect and offering little indication of their tumultuous past or potential future. When I asked a driver taking me to the oil workers union in San Fernando, Trinidad's largest city in the south, who owned the cane fields he said he didn't know. I asked him when the last time the fields were harvested. He hesitated then offered, "Around here? Maybe ten years." Do you think sugar will ever come back? "The people don't want that. I don't think you could find anybody to do that work now."

The vagaries of the global agriculture market certainly affect all nations and their various industries. In this sense, Trinidad and other countries of the Caribbean are not alone. However, what is equally evident is the disproportionate effect the destruction of key industries can have on small nations. Economic hegemons like the United States or the European Union can suffer the dismantling of even several industries with only marginal changes in GDP $[17,20]$. Smaller countries, particularly those systematically underdeveloped throughout colonial control, often struggle to survive the erosion of a single industry.

\section{As Oil Goes, So Goes Nutrition}

The changes in Trinidad's economic landscape wrought by structural adjustment policies implemented in the 1980s

9 See the following data sets and tables listed in the bibliography: invest $\mathrm{tt}$; Central Bank of Trinidad and Tobago; Inter-American Development Bank; CIA World Factbook. inaugurated a new suite of pressures on Trinidad's populace. At the beginning of the structural adjustment programs, which called for greater participation in global trade networks, child undernourishment stood close to an alarming 20 percent. As Trinidad has adjusted its economy to meet new demands the effects of structural adjustment on undernourishment gave way to a reverse problem excessive calorie intake, obesity, high blood pressure, and the rise of type 2 diabetes, which, incidentally, is expected to increase the most in developing countries (WHO). KFC's decadent menu, with items such as the Double Down (a fried chicken, bacon, and cheese sandwich), which clocks in at close 1,200 calories, creates a set of health problems at the other end of the scale from undernourishment. Add to the chicken/bacon sandwich a 16 ounce soda at around 250 calories, and a side of fries with ketchup at around 550 calories, and a diner at the dazzlingly busy KFC in Port of Spain can easily wolf down 2,000 calories, mostly from fat and sugar, just for lunch ${ }^{10}$.

In a sign of just how linked Trinidad's food supply, and thus access to nutrition, is to the global economic order, undernourishment rates pace global oil prices in an inverse relationship. As oil and natural gas prices rise, undernourishment rates fall. When oil and natural gas prices plummet, as they are currently doing, undernourishment rises. As an oil producing country with less than four percent of its population engaged in agriculture, and much of that output devoted to export crops such as cocoa and coffee production, Trinidad is ranked as a high import dependent country for food. With food prices currently spiking, and oil prices at their lowest in five years, Trinidad's high population below the poverty line, currently standing at 19 percent, again faces the harrowing possibility of a climbing undernourishment rate. As a part of a continuing ethos of structural adjustment and the neo-liberal "great risk shift" logic it follows, subsidies for Trinidad's ailing farmers, who recently complained of their inability to compete with large foreign producers and the prohibitively high prices of fertilizers and insecticides, remained relegated only to emergency needs. As Vasant Baranth, Minister of Food Production, told the farmers, "We must understand that this is a platform of mutual respect, where co-operation does not mean taking advantage of the ministry...we do not intend to spoon-feed you for any length of time" [21].

Speaking on the occasion of Puerto Rico's decision to become a vassal state of the United States, Prime Minister of Trinidad Eric Williams rhetorically asked, "What does it profit a nation to secure prosperity but lose its soul?" A staunch nationalist and critical historian of imperialism in the West Indies, Williams worried that the metropolitan powers to the North, particularly the US, would find clever new ways of reasserting control after the wave of independence movements that swept the Caribbean in the 1960s and 70s.

\footnotetext{
${ }^{10}$ Idealcalorie intake is far from an exact science. However, there is rather widespread agreement that even fairly active to vigorously active adults typically do not need more than about 3,000 calories a day. Most recommendations are indeed far below that, at around 2,100 to 2,500, making KFC's Double Down criminally excessive.
} 
Eager to build a united West Indies Federation that could effectively contend with the western industrial powers, Williams feared that Caribbean states insecure about their ability to remain economically solvent would forfeit independence for a steady check, just as Puerto Rico had done and as the French territories - Martinique, Guadeloupe, and French Guiana -would do in 1962. Williams's fears were realized when the West Indies Federation dissolved before it even started. The spirit of independence that Williams hoped to cultivate, not just in Trinidad but throughout the Caribbean, was not merely an issue of economics, but rather one of an indigenously inspired ethos, though he undoubtedly saw the two as intertwined. The ingenuity, creativity, and vision that lay dormant under colonial rule could be tapped, Williams contended, and thus signal to the paternal powers that the West Indies was no longer dependent on them for growth and development [22]. Seen from Williams's position, and that of other West Indian nationalists aspiring to move beyond western dependency, the modern era of globalization and neo-liberalism bears an uncanny resemblance to the divisive techniques of control mobilized with guile and savvy throughout the colonial project. The Kentucky Fried Chicken at Independence Square, towering above one of Trinidad's iconic figures of nationalism, Captain Arthur Cipriani, is one of many ironic juxtapositions one finds in the independent Caribbean.

\section{Conclusions}

The KFC at Independence Square in downtown Port of Spain stands as testament not only to the changing food consumption patterns of people throughout the world, but also to the changing means of food production and the security questions raised by high dependency on imported foods. The gaudy KFC, swarmed by hawkers and vendors of all types outside, and filled with patrons gnashing into fried foods and guzzling sugary beverages inside, is also emblematic of a new kind of post-coloniality that has been in the making for some time. Perhaps it is this post-colonial state, one that has its origin in the hierarchical ideologies of empire - coloniality - that has made nationalism such a confounding enterprise for scores of Trinidadian leaders. Naipaul's observation that Americana is synonymous with modern sophistication in Trinidad, hence the trade of locally produced, mountain grown coffee for Nescafe, is equally evident in the prominence of KFC. But there is more at stake than whether a Trinidadian chooses a local fried chicken vendor over a larger American chain. At issue is the high reliance on imported foods and the security questions this scenario raises; consumption patterns that raise diabetes and heart disease to precipitous levels; and the lack of independence engendered by a global order that demands competition on a playing field far from level. These issues are linked in a larger assemblage of nationalism and the difficulties faced by small, underdeveloped, post-colonial countries attempting to forge robust economies in the face of national disinvestment.
Globalization theorists often speak of 'flows', movements of people, things, ideas, that alter local and global landscapes (perhaps the most influential voice here is Appadurai [22]). This global cartography of flows increasingly includes the mapping of food, food security and the flow of calories throughout the world. Critically needed within these mappings are analyses of the various political-economic factors affecting local increases and decreases of calories, especially where development policy is concerned. For Trinidad, the most salient example of political economy affecting nutrition is how the fluctuation of oil prices causes fluctuations in calorie intake. High oil prices generate a more robust economy and spells greater wealth for Trinidadians more broadly. Lower oil prices generate the opposite effect a weaker economy and less wealth for more Trinidadians. The quantity of nutrition accessible to many Trinidadians when oil prices plummet drops precipitously. The problem, however, is obvious: small nations with less diversified economies feel the impact to one of its industries much more radically than countries with well-established economies. This is especially true if one of those industries is a cornerstone of the state's economy, as oil is for Trinidad. The fluctuations in geo-economic processes has a direct effect then on local food consumption and nutrition patterns, which is likely less true of more powerful countries. In tandem with global flows of fast food consumption patterns, it becomes evident that smaller countries are more vulnerable to the deleterious effects of certain flows than others. Food security, adequate nutrition, and excessive calorie consumption are thus all linked in sometimes rather unintuitive ways. The point I wish to make here concerns two intersecting lines of ethnographic inquiry. The first is that the "fragments" [3] from which a nation imagines [23] and composes its "constructed primordialism" [22], or, its foundation myths, are affected by countless internal and external factors. Small, post-colonial states face the daunting task of constructing foundation myths in a global system that benefits hegemonic states. Further complications arise for places like the Caribbean, an immigrant archipelago, where primordialisms of ancestral landsloom large in public imaginaries. The second line of inquiry is an attempt to identify and analyze certain assemblages - here the link between colonialism, nationalism, economics, and food consumption patterns - in order to understand how certain cultural logics and policy assumptions affect what people eat and the differential access to nutrition. Taken together, these lines of inquiry prompt us to consider the historical political-economic forces affecting contemporary patterns of daily life in post-colonial worlds. As the case of Trinidad and Tobago illustrates, even the most mundane of acts are bound up in webs of meaning [24] and power.

\section{REFERENCES}

[1] Rabinow, Paul, George Marcus, James Faubion, and Tobias 
Reese. Designs for an Anthropology of the Contemporary. Durham: Duke University Press, 2008.

[2] Knight, Franklin W. The Caribbean, The Genesis of a Fragmented Nationalism. New York: Oxford University Press, 1990 .

[3] Chatterjee, Partha. The Nation and its Fragments: Colonial and Postcolonial Histories: New Jersey: Princeton University Press, 1993.

[4] Johnson, Harry. Economic Nationalism in New States. In, Nationalism, John Hutchinson and Anthony D. Smith, eds. Oxford: Oxford University Press, 1994.

[5] Wilk, Richard. Food and Nationalism: The Origins of "Belizean Food". In, Food Nations: Selling Taste in Consumer Societies. Warren Belasco and Philip Scranton, eds. New York: Routledge, 2002.

[6] Biehl, Joāo. "Ethnography in the Way of Theory." Cultural Anthropology 28(4): 573-597, 2013.

[7] Brereton, Bridget. A History of Modern Trinidad 1783-1962. Champs Fleurs: Terra Verde Resource Centre, 2009.

[8] Williams, Eric. History of the People of Trinidad and Tobago. St. Austine: University of West Indies Press, 1980.

[9] Thomas, Roy. Oil Industry Profit Situation. In, The Trinidad Labour Riots of 1937: Perspectives 50 Years Later, Roy Thomas, ed. St. Augustine: University Of the West Indies Press, 1987.

[10] Lewis, Gordon K. The Growth of the Modern West Indies. New York: Monthly Review Press, 1968.

[11] Trouillot, Michel-Rolph. Haiti: State Against Nation: Origins and Legacy of Duvalierism. New York: Monthly Review Press, 1990.

[12] Naipaul, V.S.The Middle Passage: Impressions of Five Societies - British, French and Dutch - in the West Indies and South America. London: Penguin Books, 1978.
[13] Forte, Maximillian. Ruins of Absence, Presence of Caribs: (Post) Colonial Representations of Aboriginality in Trinidad and Tobago. Gainesville: University Press of Press, 2005.

[14] Wilk, Richard. Learning to be Local in Belize: Global Systems of Common Difference. In, Worlds Apart: Modernity Through the Prism of the Local. London: Routledge, 1993.

[15] Miller, Daniel. Coca Cola: A Black Sweet Drink from Trinidad. In, Material Cultures: Why Some Things Matter. Daniel Miller, ed. Chicago: University of Chicago Press, 1998.

[16] Chang, Ha-Joon. Kicking Away the Ladder: Development Strategy in Historical Perspective. New York: Anthem Press, 2003.

[17] Chang, Ha-Joon. Bad Samaritans: The Myth of Free Trade and the Secret History of Capitalism. New York: Bloomsbury Press, 2009.

[18] Jameson, Fredric. Postmodernism or, The Cultural Logic of Late Capitalism. Durham: Duke University Press, 1999.

[19] Black, Stephanie. Life \& Debt. New York: New Yorker Films Artwork, 2003.

[20] Rodrik, Dani. Has Globalization Gone Too Far? Washington, DC: Institute for International Economics, 1997.

[21] Trinidad and Tobago Newsday, Tuesday, March 22, 2011.

[22] Ryan, Selwyn. Eric Williams: The Myth and the Man. St. Augustine: University of West Indies Press, 2009.

[23] Appadurai, Arjun. Modernity at Large: Cultural Dimensions of Globalization. Minneapolis: University of Minnesota Press, 2003.

[24] Anderson, Benedict. Imagined Communities: Reflections on the Origin and Spread of Nationalism. London: Verso, 1991.

[25] Geertz, Clifford. Thick Description: Toward an Interpretive Theory of Culture. In, The Interpretation of Cultures. Basic Books, 1973. 